\section{Polarographic Researches in Chemical Kinetics}

\author{
By Y. Nagata
}

Department of Agricultural Chemistry, Faculty of Agriculture, Kyoto University
化学反応のポーラログラフ的研究

$$
\text { 永问关之㫾 }
$$

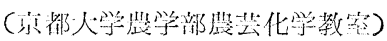

(Received on Oct. 15, 1956)

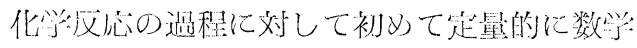

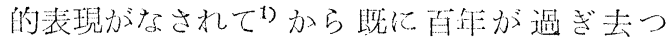

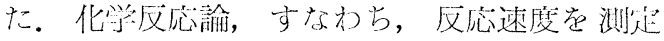
し，旮在在するすへてての因子考察する科

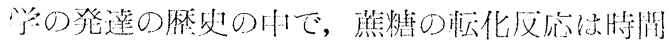

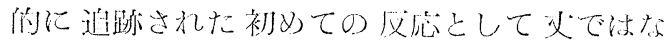

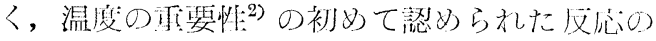

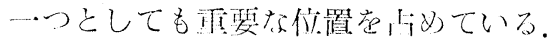

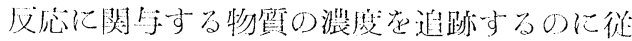

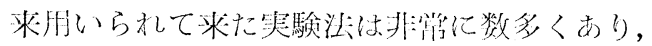

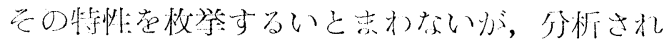

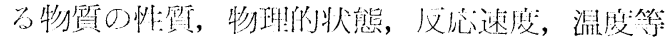

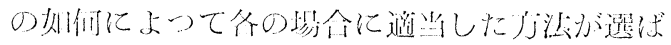
れて来た。作し，乙れらの邀当な广江の外に，

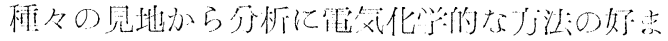
しいてとがしばしばあることを強周しなくては

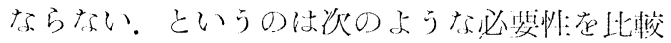

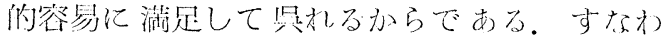

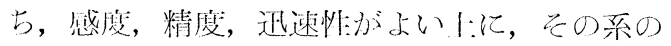

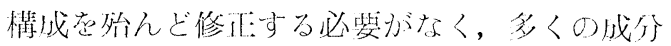

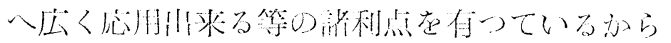
で晾る。

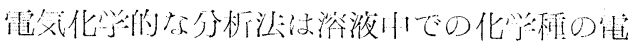

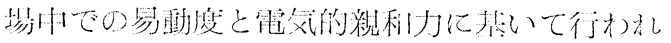

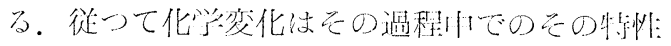
の俻の変化によつて砄究される。

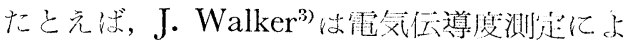
つてエステルのアルカりによる加水分解を迫跡

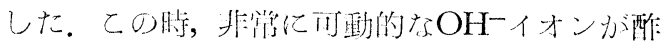
陵イオンで置換されるから㑂導度は減少する。

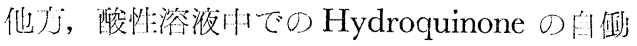
酸化の電位养滴定的䂙究は V. K. La Mer, J. W. Temple によつて初放て行われ，乙の反応 速度は系の自目エネルギーに比例している。

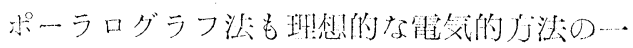
つと考光られ，无れ白休特殊州を有しているか

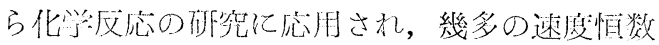
が測定されて来た。 ポーラログラフ法はをの很

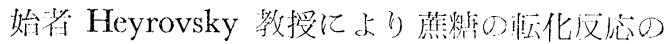
研究に初》て利用された5)。

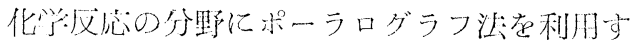

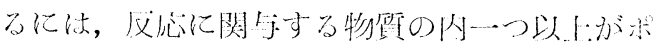
一ラロ们に活州であることが必装である。例党

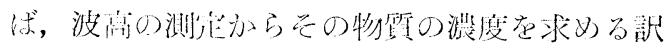
であるが，とれは行に Ilkovic 式在䏘るか或

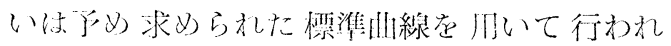

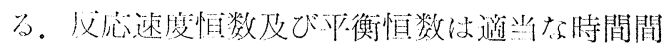

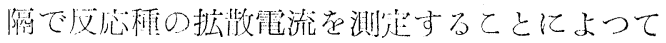

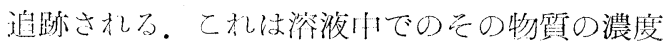

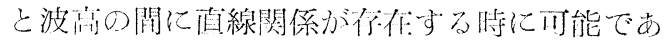
万.

ポーラログラフ泛の精度は文底速庭破究に必

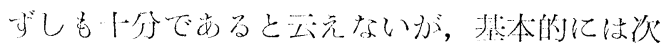

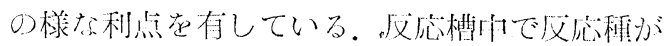

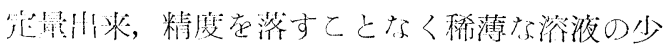

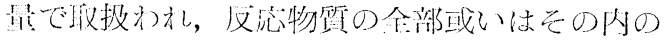

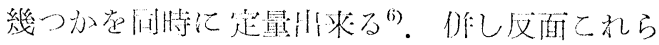
の特幑は他の方法では見られないとててである

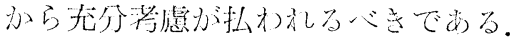

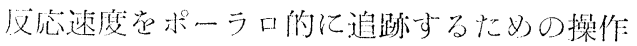

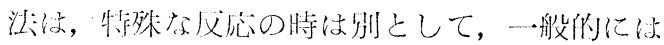
次の様にして行われる107,109,15).

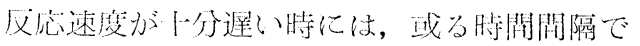

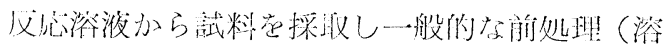

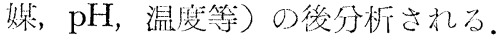

作し, 同一反应容器中で反応存連続的飞追跡

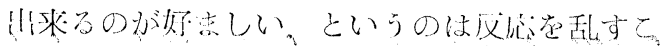


となく少量で分析出来るからである。遅い反心 の㭙には時々ポーラログラム蕰とり，之に㕅し て速い反応では (半減期数分) 短時閒に武料芭 採取して反応を止めポーラログラムをとること が乔来ないから上の連続法が利用される。

この様な場合の電流滴定方式は反応物質の一 つが直接测定出来る様な波を示す時に可能であ つて, 電流值は限界電流以達している或る一筀 電位で測定される。

得られた曲線図の軸の一つは時間軸になる。 限界電流は復極剂の濃度に比例する時はその曲 線は時間の雨数として反応物質の濃度学表わし ている。

この方法は特に自㗢酸化反忘の砄究にとつて 非常に有效であつて，酵母による溶存酸素の游 費率の研究に J.P. Baumberger ${ }^{7}$ によつて初め て利用された。

\section{〔I 互変異性反応}

同一物質の互変型はしばしば異つたポーラロ グラム走示すととがある。たとえば, Keto-enol 平衡ぶそれであつて 2 ケの原子団が関係してい 弓.

$$
-\mathrm{CO}-\mathrm{CH}_{2}-\text { 及び }-\mathrm{C}(\mathrm{OH})=\mathrm{CH}-
$$

この時若し特別な条件があれば，一つの型か ら他の型えの転移速度及び平衡濃度が容易飞測 定州来る。

光觉的不旋向化及び共鳴の現象は電極表面で のその構造変化速度を測定出来るから，時によ っては正確に分析されている。

これらの研究例として Benzoin と Desoxybenzoin に対して行つた G. Semerano ${ }^{8)}$ の泀究 が思い活される。溶液の $\mathrm{pH}$ の如何に拘わらず その分極曲線から，乙れらの物質は溶液中では 王として Keto 型として存在すると絬論されて いる。

之に㕅して, Acetoacetic ester と Acetylacetone 2 つの型として平衡して㧍り, 得られた

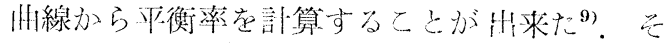

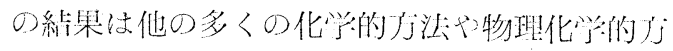
江に上る值とよく一致している。

(, T. Borcherdt, H. Adkins $s^{10)}$ 飞. り $l-p-$
Chlorobenzhydrylidene- $\alpha$-phenylethylamine 加 $\alpha$-Phenylethylidene- $p$-Chlorobenzhydryla-

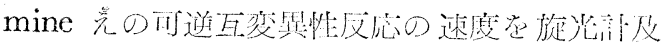
びポーラロ法で求め，反応混合液の挍光度の減 少及び加水分解による $p$-Chlorobenzophenone の Acetophenone に対する比を測定した。 之に

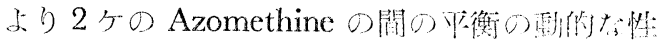
筫汃明らかルなつた。

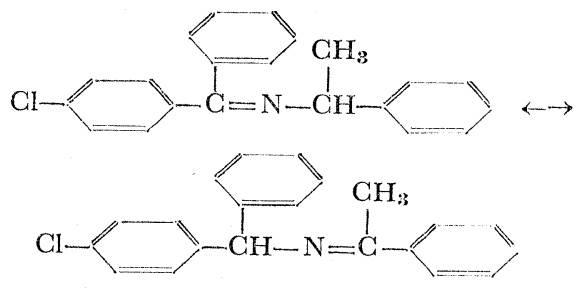

Dibenzoylmethane $\odot \alpha$-Oxybenzalacetophenone えの転移は R. Pasternak, H. v. Halban ${ }^{11)}$ によつて砸究された。雨化合物はアルカリ溶液 中で全然異つた挙動を示す。即ち，Keto 型は 2 ケの波を生じ，Enol 型の波は一つ丈である。 転移速度は酸性溶液中で測定され，その反心证 一次である。

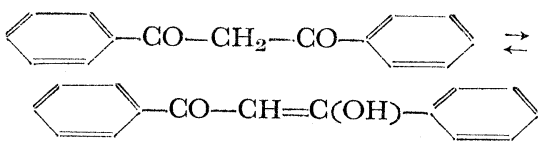

Nitroparaffin では波高と濃度の関係值線 からはづれ，アルカリ性溶液中では波が全くな くなるのはニトロ化合物のAci 型への転移によ るものであると Th. De Vries, R. W. Ivett ${ }^{12)}$ は考光た. 4 ケのNityoparaffin, Nitromethane, Nitroethane，1-及び 2-Nitropropane が緩衝溶 液中で夫々のAci 型に転移与る速度が E.W.

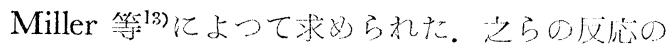
速度怕数が測定され，反応は一次であり间時に 逆反店を含んでい\%。产衡の位犆传6 110 pH 籁用で各化合物について求められ, 適当な $\mathrm{pH}$

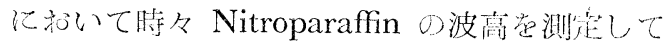

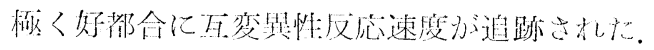

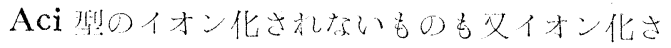

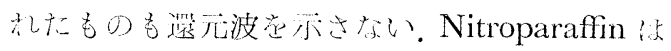

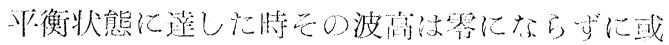
る小さい值で一定になっ。とのとと注 Acid-

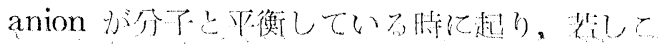


の状態で緩衝㴦液の酸成分が加元られると，

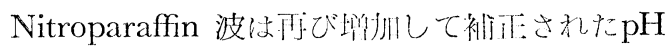
に相当する最終時高飞造する ${ }^{14)}$. 反応速度は Nitromethane $\rightarrow$ Nitroethane $\rightarrow$ 1-Nitropropane $\rightarrow$ 2-Nitropropane の順に減少す\%。

K. Schwabe, H. Berg ${ }^{15)}$ は鉱酸けでの Citral

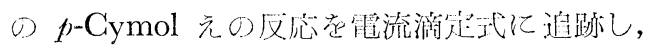

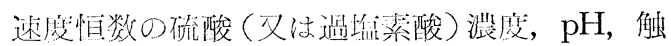
媒としての有機酸の效果老恰当し, 溶媒（エ夕 ノール）の效果を調ベた。

1-Oxycynnamic acid は光により次式の则く, Gis 型より Trans 型飞变化し，アルカリ州度 る程その反応は促進される ${ }^{16)}$.

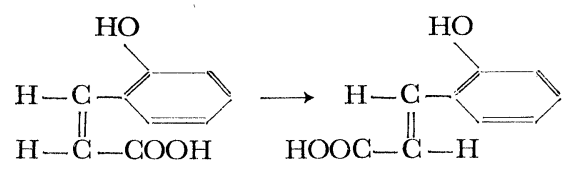

\section{〔 $\pi$ 分 解 反 応}

Maleic acid を熔融した時生すずる Fumaric acid の形成反店は均-...分子反応で，37Kcal の活州化エネルギーを有し, 頻度因子は多くの 一分子反応に見られるものと间じ order にして 温度に無関係である ${ }^{17}$.

Tungstic heter-polyanion の也来の機棈は形 成反心速度から P. Souchayにより明かにされ $た^{18)}$.

その外, Streptomycin のアルカリ溶液中で の分解は, Bricker, Vail ${ }^{199}$ とつて追跡されて いる。

Diazo 化合物の光分解はオッシログラフを用 いて F.C. Snowden ${ }^{20)}$ そりその極めて速い反 忍が研究され，朝日 ${ }^{21)}$ によて Naphthoquinone の光分解速度が測定されている。

\section{〔III〕添 加 反 応}

Glycine と Monojodoacetic acid の反灾は R. Brdicka2) そよつて破究された。 Monojodoacetic acid は well-defined な波を生し，Acetic acid 亿還元される。界つたpH溶液中で連続的 飞波高を測定すれば必灾は 2 段階に行われ，そ の時 Glycine anion のふふが応論的に活性であ

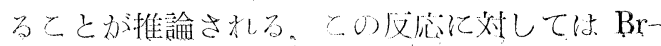

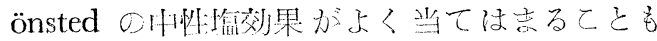
示された。

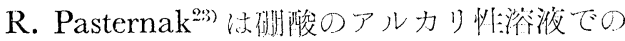
Benzil 波の減少汃ら，Benzil と碵酸水らポーラ ログラフ的に不活性:尔錯嫶の形成されるとと老

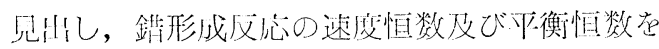

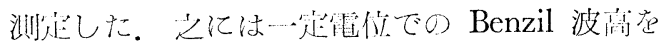
测定する乃式を採用した。この今法を用いれば

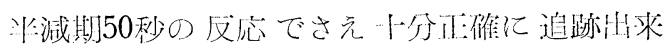
る。乙の反応は䃆酸 2 分子と Benzil 1 分子走

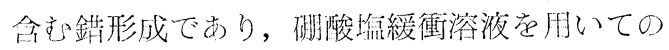
カルボニル化合物心砄究にはかかる鉛形成に注 甞す心゙きである。

飽和アルデヒド及びケトンの定最に刘する Lupton-Lynch の洼 ${ }^{24}$ —Oxime 又は $\mathrm{Hy}$ drazone 在形成させて後にのみポーラログラフ

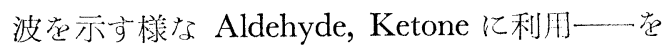
用いれば，Mesoxalic acidの Oxime 及び Hydrazone の形成反心か Sartori, Gaudiano"25) によつて哬究された，一次反柋であるが，渦程 は思われる様に簡㕷なものではない，坿となれ ば，酸性溶液中で 1 時閒以内に平衡に達してい ろが，乙の様子溶液中では Oxime 又は $\mathrm{Hy}$ drazone の形成は一般には容易に行れれる筈が ないからである。

Schrauftätter, Deutsch ${ }^{6)}$ は o-Oxyacetophenone と 5-Bromosalicylic aldehyde か.ら 5-Bromo-2,2'-dioxychalcone の形成される反応を研 究し，3物質は共に別個の波を示すから各仅灾 稞の濃度が測定された。尚，反応は二次であ る。

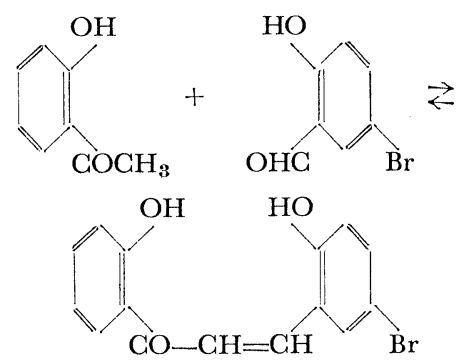

Monomethylolurea, Urea 及び Formaldehydeの間には一つの平衡があり, Formaldehyde の波高の測定汃ら Crowe, Lynch ${ }^{26)}$ 飞よ れば, 等温での稀嫶基性溶液中では Monometh- 
ylolurea の約90\%が Urea 及び Formaldehyde 飞分解され，その反応は一次（逆反応は二次） である、们方向への反応速度及び平衡恒数, $\mathrm{pH}$ 及び温度の影響が斫究された。反応方程式は $\mathrm{pH}$ 又は温度による Formaldehyde のポーラログ ラフ波に対するUrea-Formaldehyde 反灾の関 係を表わしている。乙の反応速度は Formaldehyde の脱水反応速度及び Urea からの anion 形成速度に関係していると考光られる。<smiles>NC(N)=O</smiles>

B. Vlcek ${ }^{277}$ は Monoiodoacetic acid と脂肪酸 の間の反灾により生成する Iodide ionの波高の 增大により追跡し, R. Custi 等年 Semiquinone の酸性溶液での重合反応老研院し た. Ketosteroid と Amine の反応は M. Brezina 等尔により, 又 Amino acidと Carbon disulfide との結合速度は R. Zahradnik 等30) より報告されている。

Citral と Acetone の縮合反応惊 K. Schwabe, H. Berg ${ }^{15)}$ そよ生成物の Pseudoionone の波 高測定から追跡され，反応は $\mathrm{LiOH}$ そより接 触され， $\mathrm{pH}$ の大子る程速度恒数は増大し，温 度効果よりその活性化エネルギーは13Kcalであ る。

W. Dirscherl, H. Bergmeyer ${ }^{311}$ はアルカリ性 溶液中での Acetaldehydeの Aldol-condensation を研究し, Formaldehyde と Protein の縮合に

\section{$2 \mathrm{CH}_{3} \mathrm{CHO} \rightarrow \mathrm{CH}_{3} \mathrm{CH}(\mathrm{OH}) \mathrm{CH}_{2} \mathrm{CHO}$}

ついては, S. Fiala ${ }^{322}$ そり 追跡されている。 無水 Hydrazine 中での Acetophenone, Benzophenone の如きカルボニル化合物は Hydrazone 在形成するが， C. Furlani ${ }^{33)}$ 亿よれば反応は溶 媒の組成によつて異なり, 酸により接触され, その活州:化エネルギーは18Kcalである。

\section{〔IV】 酸化還元反応}

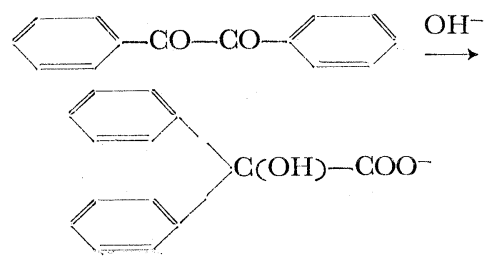

Benzil-Benzilic acid の枟移反灾心二次反店で アルコール溶液中のBenzil 波の低下に与りA.

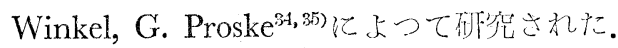

H. Adkins, F.W. Cox ${ }^{36)}$ は次の様な反忘の速

$$
\mathrm{R}_{2} \mathrm{CO}+\mathrm{R}_{2}{ }^{\prime} \mathrm{CHOH} \rightarrow \mathrm{R}_{2} \mathrm{CHOH}+\mathrm{R}_{2}{ }^{\prime} \mathrm{CO}
$$

度と平衡濃度を決定した。種々のアルコールの 比適元力及び夫相応する Ketone の酸化力以 二三の場合ての様にして求められた。

Tyrosine は醉秦の作用によつてRed-quinone と Dihydroindol 亿酸化されポーラログラフ汇 により追跡されている37).

Adrenochrome から Melanine ぶ形成される 第一段階は一次反応であつて，高 $\mathrm{pH}$ 亿扎いて 迅速に進行する。その際 Adrenochrome 波峦 低くなり，それに伴つて酸化波ぶ現われ\%。 V. Zambott，V. Moret ${ }^{33)}$ 飞子れば反応埌次の

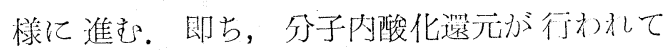
N-methyl-3-Keto-5,6-dioxindol (II) が形成ざ れ, 次いで Enol 化により N-methyl-3,5,6-trioxindol (III) そなる。
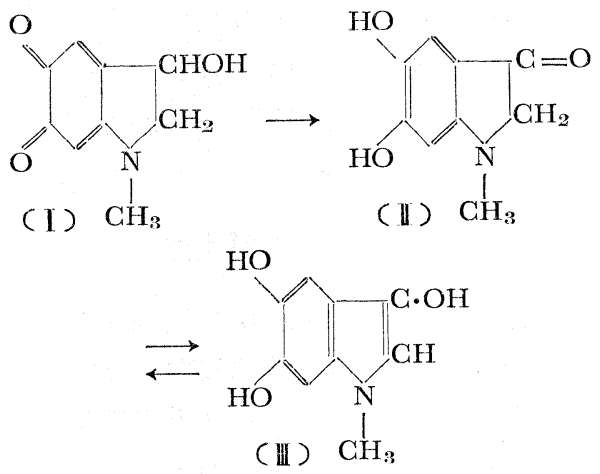

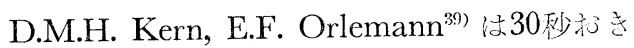
そ +0.1 v. vs. S.G.E. の電位でのU(V)の桩散 禹流在測定して異なつた洪度でのU(V)の不均 衡反忘速度を求棉。この䋨果は同一の問題と 取組んでいる多くの人々の作究に反応論的表現 在与えた ${ }^{40 \sim 44)}$. 拡散電流の逆数と時間の間の一 次的関係は反応速度少 U(V)の瀑度の自乗に比 㤡与るとと定示している。

$\mathrm{H}^{+}$ion の活量飞対导る関係については密惔 尔比例性が存在し，U(V)の不均衡反心速度

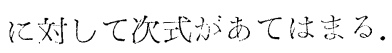

$$
-d\left[\mathrm{UO}_{2}{ }^{+}\right] / d t=k a_{\mathrm{U}}\left[\mathrm{UO}_{2}{ }^{+}\right]^{2}
$$


渦㙏菜酸塩溶液山での最も可能子機構は

$\mathrm{UO}_{\mathrm{s}}{ }^{+}+\mathrm{H}^{+}=\mathrm{UOOH}^{++}$,

$\mathrm{UO}_{2}{ }^{+}+\mathrm{UOOH}^{++} \stackrel{k^{\prime}}{\rightarrow} \mathrm{UO}_{2}{ }^{++}+\mathrm{UOOH}^{+}$,

$\mathrm{UOOH}^{+} \rightarrow$ Stable $\mathrm{U}(\mathrm{V})$ species. である。

R.H. Betts ${ }^{45}$ 结 $\mathrm{SO}_{2}$ の冷溶滩中で $\mathrm{Pu}(\mathrm{IV})$ 小

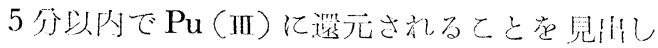

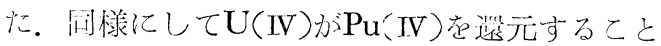

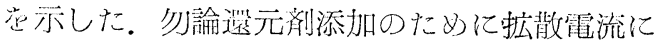

$2 \mathrm{H}_{2} \mathrm{O}+\mathrm{U}^{4+}+2 \mathrm{Pu}^{4+} \rightarrow \mathrm{UO}^{2++}+2 \mathrm{Pu}^{3+}+4 \mathrm{H}^{+}$ 抄害を与えないととを碓めるために邀当なブラ ンク・テストがなされ尔くてはいけない。 P. Souchay ${ }^{46)}$ はポーラログラフ法が迅達なガス炎

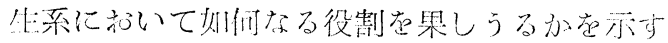
ために Hypoiodite の分解の研究者した。

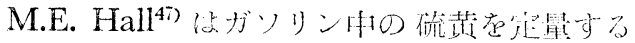

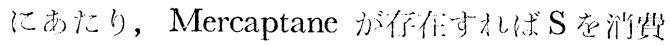

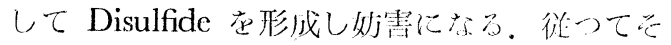
の盗度か湘官されている。

\section{$\mathrm{S}+2 \mathrm{R} \cdot \mathrm{SH} \rightarrow \mathrm{RSSR}+\mathrm{H}_{2} \mathrm{~S}$}

Iodosobenzene は不均衡反忘に上り

$2 \mathrm{C}_{6} \mathrm{H}_{5} \mathrm{JO} \rightarrow \mathrm{C}_{6} \mathrm{H}_{5} \mathrm{~J}+\mathrm{C}_{15} \mathrm{H}_{5} \mathrm{JO}_{2}$

の阴く変化し, その速度が G. Sartori, C. Furlani $^{48}$ に与求められた。

\section{[V] 加水分解反応}

Ketose の波润はその湦度に比例するので，

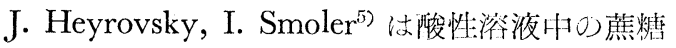
の転化速度を求內た。一定の開隔で陵性蔴糖溶 液の一部を取出し，LiOH で微アルカリ性にし 稀勫してポーラログラフで钼祭した。この様に

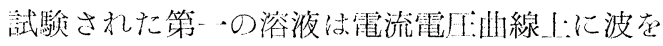
山さなかつた。 3 時閏後の第 2 の溶笵は明らか 示波を示し，時間が絴つにつれて波は大きくな り遂には限界值に達する。陖の洪度の增大と其 そ枟化速度も增加する。

拡散電流の限界值は蔴煻の完全分解を示して いる．徒つてそれは蔴桾の元の量 a 表わして いる。時間 $\mathrm{t}$ 後の波高 $\mathrm{x}$ は形成された Fructose 双は分解された蕉煻の量老敖わしている。

$$
k=\frac{1}{t} \log \frac{a}{a-x}
$$

祭万武存用いれば転化速度恒数は夷際一定にな

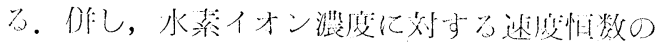

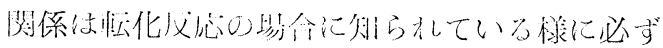
しも消線閵係ではない，速度恒数は酸度の增加 から期待されるより余訃湆加している。この ことは Glucoseの是是の現法が直接法である一

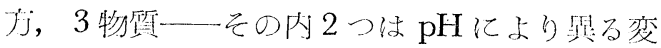
能光を行う一一の偏光の效果の組命は+に基い

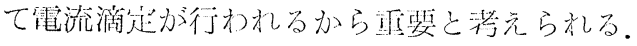

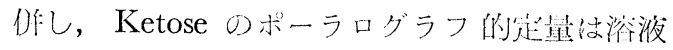
が新しくても㕛何日か経つたものでも波高が... 定であるから，偏光には全然影劉されない，彷 つて電啃での反応に関する最近の破究に刘して

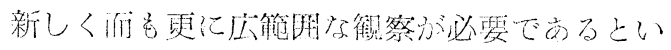
う等実に注意すべきである。

Vinyl acetate $の$ 加水分解《. O. Samuclson ${ }^{49}$ ぶ作究した。

$$
\begin{array}{r}
\mathrm{CH}_{2}=\mathrm{CH}-\mathrm{OCO}-\mathrm{CH}_{3}+\mathrm{OH}^{-}- \\
\mathrm{CH}_{3} \mathrm{CHO}+\mathrm{CH}_{3} \mathrm{COO}^{-}
\end{array}
$$

㖄分解により比ずる Vinyl alcohol は但ち に Acetaldehyde に Isomer 化する. Acetaldehyde は沙命液中で㫿一のポーラログラフ的に 活攸な成分であり，兴の過程は $\mathrm{pH}$ と温度の函 数として表わされ, 速度恒数は温度に対して普 通とは翼つた関係にあることが涩められた。

アルカリ性溶液で Glycolic acid と沃化水素 陵 Brdicka $^{50)}$ 飞より櫧究され，之は滴下水銀電極

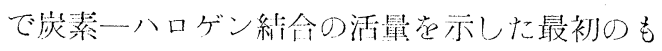
のである。

E. Saito ${ }^{51,52)}$ は-及び $\beta$-Bromopropionic acid の加水分解在研究した。 H. Matheson, H. S. Isabell, E.R. Smith ${ }^{53)}$ は Polyhydroxymonocarboxylic acid $の$ lactone, lactide 及び縮合成生 物の加水分解反忘老調心゙た。

アルカリ性溶液中の Benzyl-bromide の加水 分解は R. Pasternak, H. v. Halban'11) 飞方 て追跡された。得られた波は未だ变化し后い Bromideの港度に比例し, 反忍は Benzyl-bromide について一次である. H. H. G. Jellinek, A. Gordon ${ }^{54)}$ は㙁訟溶液打 Nicotinamide の 加水分解を矿究した，反㐫は一分開隔でAmide 
の灌废を定量してボーラログラフ的に追跡さ れ，Amide に関して一次反応である。文活性 化エネルギーが計算され，中性塩效果は正で ある。速度恒数の塩酸濃度に刘する 関係市ら Bivalent amide cation $\mathrm{H} \cdot \mathrm{RCONH}_{3}{ }^{+}\left\llcorner\mathrm{H}^{+}\right.$ion の閒の反忘が律速段階であると仮定された。

其の他, Coumarin ${ }^{55,56)}$, Cyclohexanone oxi$\mathrm{me}^{57)}, \pi$-Oxocamphor-diacetate ${ }^{587}, 2$-Methyl1,4-naphthoquinone-NaHSO${ }_{4}{ }^{59)}, \quad p$-Nitraniline $の$ Acyl 化合物 ${ }^{60,61)}$, Isonicotinic-methylester ${ }^{62)}$, Isatin $^{63)}, \boldsymbol{\alpha}$-Br-aldehyde ${ }^{64)}, 2$-Methyl-naphthoquinoimine ${ }^{65)}$ 等の加水分解，又 Acetylene $の$ 触

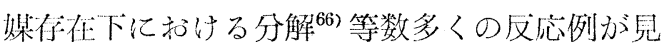
られる。

\section{〔V丁〕脱塩酸反応}

有機ハロゲン誘導体から $\mathrm{G}=\mathrm{G}$ 結合を持つた 物質の形成される反応は H. Keller, M. Hochweber, H. v. Halban ${ }^{67}$ 亿よつて初少て定量的 に研究された．DDTから $\mathrm{HCl}$ が除去される反 志をポーラロ的に追跡する暗示は非常に興味が ある．多八ロゲン化合物に対して見出された広 い忘用範用と殺菌作用の機構についての研究の た为氾も興味が多い。

この見地から興味深い化合物である BHCの 異性体 $(\alpha, \beta, \gamma, \delta, \varepsilon)$ そつて L. Jannelli, E. Gagliardo ${ }^{68)}$ とよれば, 次の 3 つの連続した 反応に従つて脱塩酸が行われ，Trichlorobenzene の混合物になる。

$$
\begin{aligned}
& \mathrm{C}_{5} \mathrm{H}_{6} \mathrm{Cl}_{6}+\mathrm{OH}^{-} \stackrel{k_{1}}{\rightarrow} \mathrm{C}_{6} \mathrm{H}_{5} \mathrm{Cl}_{5}+\mathrm{Cl}^{-}+\mathrm{H}_{2} \mathrm{O} \\
& \mathrm{C}_{6} \mathrm{H}_{5} \mathrm{Cl}_{5}+\mathrm{OH}^{-} \stackrel{k_{2}}{\rightarrow} \mathrm{C}_{6} \mathrm{H}_{4} \mathrm{Cl}_{4}+\mathrm{Cl}^{-}+\mathrm{H}_{2} \mathrm{O} \\
& \mathrm{C}_{6} \mathrm{H}_{4} \mathrm{Cl}_{4}+\mathrm{OH}^{-} \stackrel{k_{3}}{\rightarrow} \mathrm{C}_{6} \mathrm{H}_{3} \mathrm{Cl}_{3}+\mathrm{Cl}^{-}+\mathrm{H}_{2} \mathrm{O}
\end{aligned}
$$

この系は共通成分 $\left(\mathrm{OH}^{-}\right)$を持つた連続 2 分 子反応を 3 つ含んでいて興味深い. 八ロゲン化 合物のポーラログラフ的挙動の研究の後, 1:の 系滔通の化学法一一生はた $\mathrm{Cl}^{-}$ionの全量を 滴定する——比して相当の利点をもつたボー ラログラフ泛により砳究された。

3つの反灾の队一文か幄いか， 3つの速度

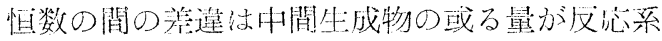

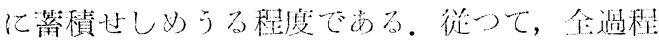
の速總分析及び问牌分析在效果似にすることが
出来当。

このことは上の文応に打いてアルカリの瀑度 在変化してなされた。 $\gamma$ 異性体の崵合には第 1 段が最も遅く，ポーラログラムには1個の波が 現われ時間と共に規則的に減少する。度応は次 式に従つている。

$$
k=\frac{1}{t} \frac{1}{b-3 a} \ln \frac{1-3 \frac{a}{b} \varphi}{1-\varphi}
$$

$a, b$ は大々 $\gamma-\mathrm{BHC}$ 及び $\mathrm{NaOH}$ の初浪莈, $\varphi$ 㹥 $x / a$ を表わし， $x$ は時䦎 $t$ 後変化した物質 の濃度を意味している。

$\delta$-BHC の場合は第 2 段ぶ最も幄く，アルカ リの濃度を適当に変えると，第 1 段が进速隹終 結して第 2 段が容易に追跡出来るか，或い法 Pentachloro 誘導体の波の增加が観察咕米え。 この誘導体は今の条件では還元性でないHexachlor一誘導体から出発している。中間のアルカ リ瀑度では，時間の承数として Pentachlor 誘 導体の 波高の表わす曲線は一つの極大を生ず る.乙の場合, 完全な数学的解析は一連の二次 反応が含志れて特に複雑であつて近似的にしか 解けない。

F. Lucena, E. Gagliardo ${ }^{699}$ は 5 個の翼性体の 界面活量を測定して反応䂺究に関聯させた。 れによれば，殺虫力の最も強い $\boldsymbol{\gamma}$-BHC はボ一 ラログラフ的にも最も易漫元性である。

\section{〔VII]自働酸化反応}

膘素を始㑑動酸化反公の中間生成物或い は最終生産物として形成される Peroxide やを の他多くの物質はポーラログラフ法により容易 亿定量されるから，種々の自働酸化反応特に酸 素が Reactant の場合に多く利用されている。 このことは重合反応にも極めて重要である。と いうの级不応鎖の出発中心を形成する能厅のあ

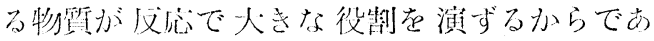
う。即ち，これらの㤈はしばしば Free-radical の性質を有し，酸化反応に上つて出発物質 (Monomer 或いは低重合物) 加ら生成される。

稀薄な溶液系に扣ける自働酸化反忘の場侖今

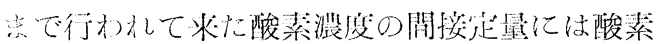
の嵒界溶解摭在考虑に人れなくてはならない。 
從つて酸素濃度の時開的変化の被究はこのため に非常に困雏であり父不正碓であつた。溶液中 の酸素の飽利篦度は溶液の化的成分, 温度, 分

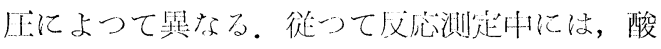

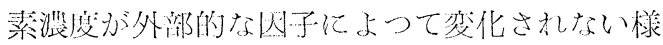

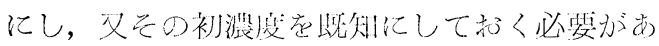
万. J. Heyrovsky, V. Vitek ${ }^{70,71)}$ 被初》てポー ラログラフ汇をな゙ス山及び水けの陖䇣含荲の测

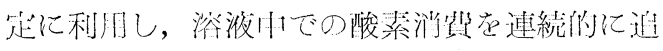
䟽した。

O.H. Müller, J.P. Baumberger ${ }^{72,7)}$ は..定雷

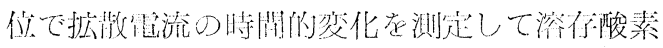
の速䌇测定にポーラロ攵ラフを利月した。陵素

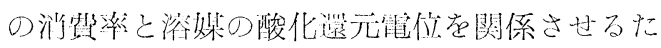
めに管全に自墈的にこの Diagram が採用され ti.

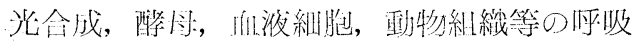

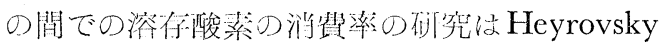

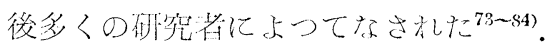

この方法は R.S. Ingols ${ }^{85)}$ 亿主水, 活州 励泥植物の矿究に応用された。

J.F. Zimmermann, L.J. Berry ${ }^{56)}$ は玉烈の截

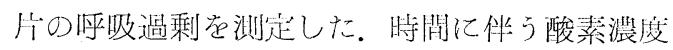
の変化が根の周辺の溶液中で連続的に追跡され

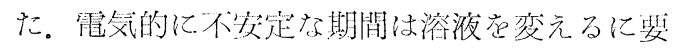
する時閒も含めて 150 秒に制限されている。乙 の様にして得られた絬果は良い再現性を有して いる.

Penicillin の定星 ${ }^{87)}$ そはポーラログラフ法が 応胕されていて，炎れはPenicillin そょる Sta一

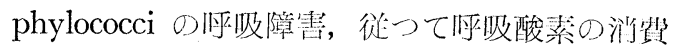

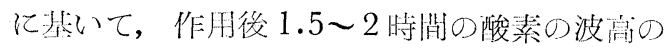
測定によつて行われた。 Penicillin が婊い程酸 素の消費法少い。即方，それ丈ポーラログラフ 波は大きい。

V.B.D. Skerman ${ }^{88)}$ ( Sulphide の荹度老定量 してバタテリヤの Sulphide 生成速度を測走し,

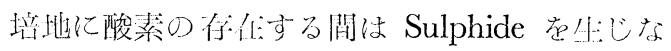
いことを見出した。

G. Semerano 等 $89,90,41)$ は稀薄浴液小での自働 酸化反忘の研究に特殊な電解糖を洘案した。

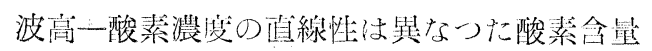

の6 偑つ溶液に対す方朘素波の測定に依つて碓 か好られた。標準は Winkler の容量法により

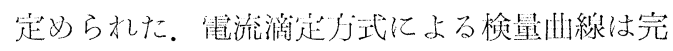

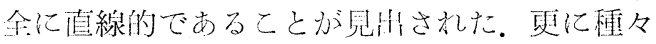
の温度での测定圭ら酸素の桩散係数及び温度係 数の走量が可能にされた。との装置を用いて $\mathrm{Na}_{2} \mathrm{SO}_{3}$ の自働婹化仅忍引゙触媒 $\left(\mathrm{Cu}^{++}\right.$イオン) 及び妨慧郕 (Glycerol) の浱度について追䟢さ れた。得られた緍果の三次元议形に上りこの與 味ある反芯の新しい見解归らかにされた。之 は Frank, Haber ${ }^{91)}$ 及び Bäckström²9 の理㖮一 - $\mathrm{Cu}^{++}$イオン, 唒素, Sulphite 以外飞 Free

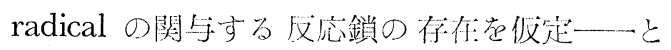
よく一致している.

塩基性溶液中での $\alpha, \beta$-及び $\beta, \gamma$-Angelica lactone による陵素の吸収は E.V. Kirkland, C. A. Reynolds, C. A. Vanderwerf ${ }^{93}$ 亿より研

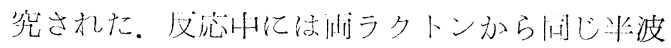

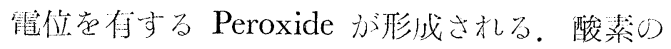
消費を拡散電流の四数としてグラフにすると， 各 Lactone に刘して一次関係ぶえられた。実 験絬果から次の機棈が絬渝された。 Lactone か らブロトンが除去されて形成される

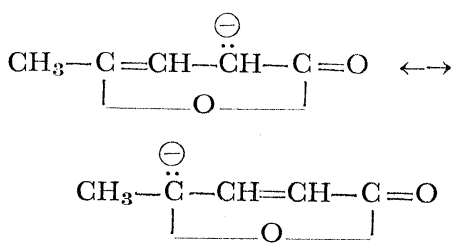

なる其啗泟成物のイオンを会んでいる。この㙨 構に㧊いては, Free radical

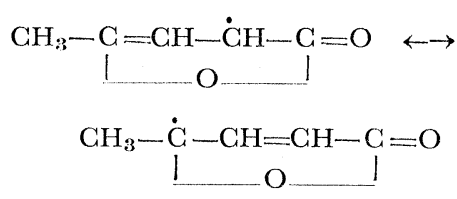

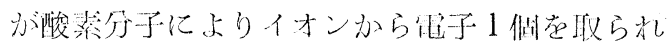
て䧈素は Superoxide イォンになる。乙の様な 機構に基くと $\alpha, \beta$-Angelica から Peroxide の 形成される速堎恒数は Lactone の訟 イオン化 反応速度恒数に一致すべきである。

W.R. Lewis 等94,95) は Fats 及び類緣 Esters の自働酸化反灾に Peroxideのポーラロ定量法 を適用した。得られた絬果は酸化つ初期では 3 
㑬の異なつた構诰の Peroxide の存在すること 棠している。或る条件の下では Peroxide Number と波高の間に一次関係が存在し，をれ から後では Peroxide Numberの増大に伴つて 波问注地しない。

Peroxide は Isopropylether の酸化反応の際 にも定量されている ${ }^{96)}$. F. Reimer ${ }^{97)}$ は Diethylether の自働酸化反応に同様に Peroxide を 定量している。

\section{〔VIII〕重合反 応}

触煤として K-persulfate を用いた Styrene の乳濁重合は I.M. Kothoff 等 ${ }^{98 \sim 100)}$ にって矿 究され，連鎖反応に重要な役割を演ずる $m$ - Di一 nitrobenzene, 酸素, Benzaldehyde, Peroxide 等の是量に滴下水銀極又は回転自金極が用いら れた。 $m$-Dinitrobenzene は妨害剂としてアル カリ性及び酸性溶液中で殆んど同程度の效果 があり，鎖を切る働きをし，従つて形成される 重合物の分子量を減少させる。 $m$-Dinitrobenzene は co-monomer として働くのではなく， 成長しつつある重合鎖と反応して最早鎖の増大 不可能な Adduct Radical を生ずることが mDinitrobenzene のなくなる速度から結論され た。

酸素による誘導期は Supersulfate の濃度に 比例し, 酸素の初分圧が一定なら馀誘導期は酸 素量に比例する。この条件の下で酸素の消失は Styrene 分子の活性化速度によつて定量され る。その速度は Persulfate の濃度に比例する。 酸素の初分圧が変り用いられた Persulfate の濃 度に比例する時, 酸素の消滅は 0 次反応であつ て一時的な Shortstop の如くに㗢いている.

\section{〔IX]雑}

E. Knobloch ${ }^{101)}$ は Aldehyde 及び Hypoxanthine の酸化を接触するミルク中の Enzym に 放射線を照射することによつて不活性にしうる ことを確めた。 2 つ接触作用は同程度に遅く されない事実から，2つの反応は同一のEnzym で接触されるものでないとよ゙判つた，Kno-

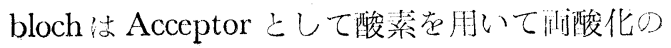

反応機構を考光て後しの結論に到達した.Sali一 cylaldehyde の酸化の時反応生成物としての $\mathrm{H}_{2} \mathrm{O}_{2}$ の存在をポーラログラフ的に示しえなか つたが, Hypoxanthine の酸化の間 $\mathrm{H}_{2} \mathrm{O}_{2}$ の 形成は定量的飞追跡された。徒つて恐らく Schardinger の Enzym は別個の 2 個の酵素より 成ると考元られる (Xanthinoxidase 及び Aldehydoxidase).

滴下水銀電極は $-0.3 v$ v. v.s. S.C.E. の筀售位 で働かせるとデアゾ化された Amine の篦度测 定用の Indicator 亿使用するととが出来る。

Amperometric Coupling Titration, Diazotization 反応速度, Coupling 反応速度等が容易 そ研究される，新しい方法はデアゾ化アミンの 婊度を測定するガス分析法又は比色法より一般 に適当である。或る場合例えば不溶性アゾ化 合物を迅速に形成するのを測定する様な時に は，ポーラログラフ法は唯一の有用な方法であ 万(102).

多くの化学反応特に界面反応の機構中のFree Radical の役割の 理論的に重要な問題は A. Miolati, G. Semerano によつて試みられ解決 された。 Bivalent 炭素及び Maleic, Fumaric acid (Dimer) の Monomer 型及び cis-, transAcotinic acid (Trimer) の Monomer 型の性 質を有している CH-COOH の形成が示され た。この研究では Polymer acid の解離恒数に 一致する熱力学的解離恒数を求めることも们米 た。

不均一反忘もポーラログラフ研究の対象にな つた。例えば, 蒸溜速度 ${ }^{103)}$, 過飽和溶液からの 低溶解性塩の 結晶化 ${ }^{104,105)}$, 低溶解性物質の沈 澱の溶解度の時間的变化 ${ }^{106)}$ が測定された。

以上の外, 所謂 Kinetic Current, 電極反応 論（オッシログラフ，ボーラログラフ，交流ボ 一ラログラフ等の利用)，吸着波等の問題に $\mathrm{G}$. Semerano $^{109)}$ は言及しているが，ここではこれ らを別稿にゆづるととにした。

\section{文献}

1) L. Wilhelmy, Pogg. Annalen, 81, 413 (1850).

2) S. Arrenius, Z. Physik. Chem., 4, 226 (1889). 
3) J. Walker, Proc. Roy. Soc., A78, 157 (1906).

4) V.K. La Mer, J.W. Temple, Proc. Nat. Acad. Sci., 15, 191 (1929).

5) J. Heyrovsky, I. Smoler, Collection, 4, 521 (1932).

6) E. Schrauftätter, S. Deutsch, Ber., 81, 489(1949).

7) J.P. Baumberger, Cold Spring Harbor Symbosia Quant. Biol., 7, 195 (1939).

8) G. Semerano, Gazz chim. ital., 65, 273 (1935).

9) G. Semerano, A. Chisiti, ibid., 66, 504 (1936).

10) G. T. Borcherdt, H. Adkins, J. A. C. S., 60, 3 (1938).

11) R. Pastcrnak, H.v. Halban, Helv. chim. Acta, 29, 190 (1946).

12) Th. De Vries, R.W. Ivett, Ind. Eng. Chem., Anal. Ed., 13, 339 (1941).

$1^{3)}$ E.W. Miller, A.P. Arnold, M.J. Astle, J.A.C.S., 70, 3971 (1948).

14) F. Petru, Collection, 12, 620 (1947).

15) K. Schwabe, H. Berg, Z. phys. Chem., 203, 318 (i954).

16) R. Patzak, L. Neugebauer, Monatsch., 82, 662 (1951).

17) P. Herasymenko, Z. Tyvonuk, Collection, 2, 77 (1930).

18) P. Souchay, Ann. Chim., 20, 73, 96 (1945).

19) Bricker, Vail, J.A.C.S., 73, 585 (1951).

20) F.C. Snowden, Anal. Chem., 22, 969 (1950).

21) 朝日: 葙学誌, 76, 373 (1956).

22) R. Brdicka, J. Gen. Chem., 19, 843 (1936).

23) R. Pasternak, Helv. chim. Acta, 30, 1984 (1947).

24) J. M. Lupton, C.C. Lynch, J. A. C. S., 66, 697 (1944).

25) G. Sartori, A. Guadiano, Gazz. chim. ital., 78, 77 (1948).

26) G.A. Crowe, Jr., C.C. Lynch, J.A.C.S., 70, 3795 (1948), 71, 3731 (1949)

27) B. Vlcek, Chem. Listy, 47, 1126 (1953).

28) R. Custi, S. Locchi, U. Landini, Ricerca Sci., 24, 2053 (1954).

29) M. Brezina, V. Volkova, J. Volke, Collection, 19, 894 (1954).

30) R. Zahradnik, L. Jensovsky, ibid., 21, 447 (1956).

31) W. Dirscherl, H. U. Bergmeyer, Ber., 82, 291 (1949).
32) S. Fiala, Ćhem. Listy, 39, 14 (1945).

33) C. Furlani, Polarografia, II. 103 (1956).

34) A. Winkel, G. Proske, Angew, Chem., 49, 611 (1936).

35) A. Winkel, G. Proske, Chem. Laboratorium Teil XXXIII. Berlin Verlag Chemie, 171(1937), Angew. Chem., 50, 18 (1937).

36) H. Adkins, F.W. Cox, J.A.C.S., 60, 1151(1938).

37) K. Wiesner, Biochem. Z., 314, 214 (1943).

38) V. Zabotti, V. Moret, Arch. sci. biol., 33, 522 (1949).

39) D.M.H. Kern, E.F. Olemann, J.A.C.S., 71, 2102 (1949).

40) I. M. Kolthoff, W. E. Harris, ibid., 68, 1175 (1946).

41) A. Foffani, E. Vecchi, L. Riccobont, Gazz. chim. ital., 79, 485 (1949).

42) H.G. Heal, Trans. Faraday Soc., 45. 1 (1949).

43) K.A. Kraus, F. Nelson, J.A.C.S., 71, 2517(1949).

44) K. A. Kraus, F. Nelson, G. L. Johnson, ibid., 71, 2510 (1949).

45.) R.E. Betts, Proc. Conf. Nuclear Chem., Chem. Inst. Can. (Ottawa), 68 (1947).

46) P. Souchay, Anal. chim. Acta, 2, 17 (1948).

47) M.E. Hall, Anal. Chem., 22, 1137 (1950).

48) G. Sartori, C. Furlani, Polarografia, Il, 267 (1956).

49) O. Samuelson, Svensk. Kem. Tid., 57, 27(1945).

50) E. Saito, Bull. Soc. chim., France, 1948, 404.

51) Ibid., 1948, 408.

52) R. Brdicka, J. Gen. Physiol., 19, 899 (1936).

53) H. Matheson, H.S. Isabell, E.R. Smith, J. Research Natl. Bur. Standards, 28, 95 (1942).

54) H. H. G. Jellinek, A. Gordon, J. Phys. Colloid Chem., 53, 996 (1949).

55) R. Patzak, L. Neugebauer, Monatsh., 82, 662 (1951).

56) A. Foffani, E. Fornsari, G. Semerano, Polarografia, II, 293 (1956).

57) Z. Vodrazka, Chem. Listy, 47, 992 (1953).

58）朝日：武四研報，13，36 (1954).

59) 胡日: 蒋学誌, 76, 370 (1956).

60) L. Holleck, G.A. Melkonian, Z. Elektrochem., 58, 867 (1954).

61) L. Holleck, H. Schmidt, Naturwiss., 41, 87 (1954). 
62) 永困, 涻, Bull. Chem. Soc., Japan, 28, 113 (1955).

63) I. A. Korschunov, Shchennikova, Zhur. Fiz. Khim., 24, 813 (1950).

64) A. Kirrman, P. Federlin, Compt. rend., 230, 1066 (1950), Bull. Sci. chim., France, 1950, 707.

65) E. Knobloch, Proc. I. inter. Pol. Congr. Prague, I, 764 (1951).

66) K. Schwabe, H. Berg, Z. phys. Chem., 203, 383 (1954).

67) H. Keller, M. Hochweber, H.v. Halban, Helv . chim. Acta, 29, 761 (1946).

68) L. Janneli, F. Gagliardo, Gazz. chim. ital., 80, 204 (1950).

69) F. Lucena, F. Gagliardo, Atti. accad. nazl. Lincei, Classe sei. fiz., mat. e nat. (VIII), 8, 241 (1950).

70) J. Heyrovsky, Arhiv. Hem. i Farm., 5, 163 (1931).

71) V. Vitek, Chem. Listy, 26, 393 (1932).

72) O.H. Müller, J.P. Baumberger, Stanford Univ., 8th Annual Winter Meeting of the Western Soc. of Naturalists, (28, XII. 1938).

73) L.R. Blinks, R.K. Skow, Proc. Nat. Acad. Sci. U.S., 24, 420 (1938).

74) S. Karsten, Am. J. Botany, 25, 14 (1938).

75) H. G. Petering, F. Daniels, J. A. C. S., 60, 2796 (1938).

76) N. Tanaka, R. Tamamusi, Repts Rediation Chem. Res. Inst. (Tokyo Univ.) No. 3, 20 (1948), 4, 20 (1949), 5, 36 (1950).

77) K.S. Karsten, Am. J. Botany, 26, 855 (1939).

78) H.G. Petening, B. M. Duggar, F. Daniels, J.A. C.S., 61, 3525 (1939).

79) H. G. du Buy, J. P. Baumberger, J. Cellular Comp. Physiol., 17, 285 (1941).

80) G. Scaramelli, Bull. sci. facolta chim. ind. Bologna, 3, 205 (1942).

81) L. Selzer, J.P. Baumberger, J. Cellular Comp. Physiol., 19, 281 (1943).

82) W.M. Manning, Trans. Wisconcin Acad., Sci., 35, 221 (1943).

83) H. J. Dutton, W. M. Manning, Am. J. Botany, 28, 516 (1941).

84) B. Warshowsky, T. E. Shook, E. J. Schantz,
Anal. Chem., 26, 1811 (1954).

85) R.S. Ingols, Swege Works J., 13, 1097 (1941).

86) J. F. Zimmermann, J. L. Berry, Biochem. et Biophys. Acta, 3, 615 (1949).

87) A. Trifonov, Collection, 13, 23 (1948).

88) V. B. D. Skerman, Aust. J. Exptl. Biol. Med. Sci., 27, 173 (1949).

89) G. Semerano, L. Riccoboni, A. Foffani, Gazz. chim. ital., 79, 395 (1949).

90) L. Riccoboni, A. Foffani, E. Vecchi, ibid., 79, 418 (1949).

91) I. Frank, F. Haber, Naturwiss., 19, 450(1931).

92) H.I.I. Bäckström, J.A.C.S., 51, 90 (1929).

93) E.V. Kirkland, C.A. Reynolds, C. A. Vanderwerf, J.A.C.S., 72, 1764 (1950).

94) W.R. Lewis, F. W. Quackeubush, J. Am. Oil Chemist Soc., 26, 53 (1949).

95) W.R. Lewis, F.W. QLackenbush, T. de Vries, Anal. Chem., 21, 762 (1949).

96) V. A. Molodovskii, M. B. Neiman, Zhur. Fiz. Khim., 23, 762 (1949).

97) F. Reimers, Quart. J. Pharm. Pharmacol., 18, 350, 19, 27, 172, 473 (1946).

98) F. A. Bovey, I. M. Kolthoff, J.A.C.S., 69, 2149 (1947).

99) I.M. Kolthoff, W.J. Dale, ibid, 69, 441(1947).

100) I.M. Kolthoff, F.A. Bovey, ibid., 70, 791(1948).

101) E. Knobloch, Collection, 12, 581 (1947).

102) A.M.L. Elofson, R.L. Edsberg, P.A. Mecherly, J. Electrochem. Soc., 97, 166 (1950).

103) M.I. Gerber, A.A. Dobrinskaya, M.B. Neiman, Trudy vseoyus Konf. Anal. Khim., 2, 585 (1943).

104) T.A. Kryukova, J. Phys. Chem. (USSR), 13, 693 (1939).

105) D. R. May, I. M. Kolthoff, J. Phys. Colloid Chem., 52, 836 (1948).

106) T.D. Parks, L. Lykken, Anal. Chem., 20, 1102 (1948).

$107)$ 永田：ポーラログラフィー， 3，24 (1955).

108) 永田:「新しいポーラログラフィー」講垍会テキ スト (1956).

109) G. Semerano, Proc. I. int. pol. Gongr. Prague, II, 194 (1951) 